\title{
The photodecarboxylative addition of carboxylates to phthalimides as a key-step in the synthesis of biologically active 3-arylmethylene-2,3-dihydro-1 $\mathrm{H}$-isoindolin-1-ones
}

\author{
Ommid Anamimoghadam ${ }^{1}$, Saira Mumtaz ${ }^{1}$, Anke Nietsch $^{2}$, Gaetano Saya ${ }^{1}$, \\ Cherie A. Motti ${ }^{3}$, Jun Wang ${ }^{1}$, Peter C. Junk ${ }^{1}$, Ashfaq Mahmood Qureshi ${ }^{4}$ \\ and Michael Oelgemöller ${ }^{* 1}$
}

\author{
Full Research Paper \\ Address: \\ ${ }^{1}$ James Cook University, College of Science and Engineering, \\ Townsville, Queensland 4811, Australia, ${ }^{2}$ Dublin City University, \\ School of Chemical Sciences, Dublin 9, Ireland, ${ }^{3}$ Australian Institute \\ of Marine Science, Townsville, Queensland, Australia and \\ ${ }^{4}$ Bahauddin Zakariya University, Institute of Chemical Sciences \\ Multan, Pakistan \\ Email: \\ Michael Oelgemöller* - michael.oelgemoeller@jcu.edu.au \\ ${ }^{*}$ Corresponding author

\section{Keywords:} \\ anesthetics; arylmethylenedihydroisoindolinones; photochemistry; \\ photodecarboxylation; phthalimide
}

\author{
doi:10.3762/bjoc. 13.275 \\ Received: 13 November 2017 \\ Accepted: 15 December 2017 \\ Published: 20 December 2017 \\ Associate Editor: C. Stephenson
}

Beilstein J. Org. Chem. 2017, 13, 2833-2841.

() 2017 Anamimoghadam et al.; licensee Beilstein-Institut. License and terms: see end of document.

\begin{abstract}
The synthesis of various 3-arylmethylene-2,3-dihydro- $H$-isoindolin-1-ones was realized following a simple three-step process. The protocol utilized the photodecarboxylative addition of readily available carboxylates to $N$-(bromoalkyl)phthalimides as a versatile and efficient key step. The initially obtained hydroxyphthalimidines were readily converted to the desired $N$-diaminoalkylated 3-arylmethylene-2,3-dihydro- $1 H$-isoindolin-1-ones via acid-catalyzed dehydration and subsequent nucleophilic substitution with the corresponding secondary amines. The procedure was successfully applied to the synthesis of known local anesthetics (AL-12, AL-12B and AL-5) in their neutral forms.
\end{abstract}

\section{Introduction}

Phthalimides and their related 3-alkyl- and 3-arylmethylene2,3-dihydro- $1 H$-isoindolin-1-ones play an important role in medicinal chemistry due to their biological activities for a wide range of therapeutic applications [1-7]. AL-12, AL-12B and AL-5 (Figure 1), for example, were described as highly active local anesthetics distinctly exceeding the efficiencies of common local anesthetics such as procaine, xylocaine/lidocaine and tetracaine [8]. Their molecular structures contain the three key elements of all local anesthetics: (a) a lipophilic aromatic ring, (b) an amide (or ester) linker, and (c) a terminal tertiary amine [9]. The original synthesis of these bioactive compounds involved a Perkin condensation followed by an amination reac- 
tion. An alternative pathway to AL-12B has been described by Couture and co-workers and incorporated an intramolecular Horner-Wadsworth-Emmons reaction as a crucial step [10]

Due to their diverse biological activities, a variety of synthetic pathways to 3-arylmethylene-2,3-dihydro- $1 H$-isoindolin-1-ones has been developed over the past two decades [10-22]. The photodecarboxylative addition of phenylacetates to phthalimides represents a mild alternative entrance to these target molecules [23-31]. The reaction utilizes phenylacetate salts as readily available alkylation agents $[32,33]$. Selected transformations have been furthermore realized on large multigram scales $[25,34,35]$ and in continuous-flow mode [36-40]. The photodecarboxylation procedure was subsequently applied to the synthesis of 2-dialkylaminoalkyl-3-arylmethylene-2,3dihydro- $1 H$-isoindolin-1-ones.
The retrosynthetic analysis is depicted in Scheme 1. The initial step comprises the photodecarboxylative addition of phenylacetate to commercially available $N$-(bromoalkyl)phthalimides, yielding the corresponding benzylated hydroxyphthalimidine derivatives as key intermediates. Subsequent acid-catalyzed dehydration [41], followed by amination [42] furnishes the desired target compounds. The amino group is introduced in the final step as it would otherwise interfere with the desired photoreaction. In fact, amines are very potent electron donors and are easily oxidized by the excited phthalimide chromophore [4346].

\section{Results and Discussion}

Initial irradiation experiments were conducted with $N$-(2bromoethyl)phthalimide (1a) and potassium phenylacetate (2a) as a model system (Scheme 2 and Table 1). The salt $\mathbf{2 a}$, gener-<smiles>CCN(CC)CCN1C(=O)c2ccccc2/C1=C/c1ccc(OC)cc1</smiles>

AL-12<smiles>CCN(CC)CCN1C(=O)c2ccccc2C1=Cc1ccc(OC(C)=O)cc1</smiles>

AL-12B<smiles>CN(CCCl)CCCN1C(=O)c2ccccc2C1=Cc1ccccc1</smiles>

AL-5

Figure 1: Molecular structures of $A L-12, A L-12 B$ and $A L-5$.<smiles>[R2]NC1/C(=C/c2ccccc2[R])c2ccccc2C(=O)N1[R2]</smiles>

$\mathrm{O}$<smiles>[R20]NCCC</smiles><smiles>[R]c1ccccc1C=C1c2ccccc2C(=O)N1C(=O)c1ccccc1</smiles><smiles>C=CC(=C)C</smiles><smiles>[R]c1cc(C=CC(=O)N2C(=O)c3ccccc3C2=O)cc(C=CC(C)C)c1</smiles><smiles>O=C1c2ccccc2C(=O)N1[10Br]</smiles><smiles>[R]C(=O)CC1=C([R])[C+]=CC=C1</smiles>

Scheme 1: Retrosynthetic analysis of AL-12, AL-12B and AL-5 (in their neutral forms) and their derivatives.<smiles>O=C1c2ccccc2C(=O)N1CCBr</smiles>

$1 \mathbf{a}$<smiles>[R]OC(=O)Cc1ccccc1</smiles>

$2 a$

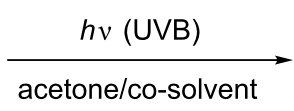

acetone/co-solvent<smiles>O=C1c2ccccc2[C@@](O)(Cc2ccccc2)N1CCBr</smiles>

$+$<smiles>O=C1c2ccccc2[C@@]2(Cc3ccccc3)OCCN12</smiles>

\begin{tabular}{|c|} 
3a \\
base (rt); acetonitrile
\end{tabular} 


\begin{tabular}{|c|c|c|c|c|}
\hline Entry & Co-solvent & $T\left[{ }^{\circ} \mathrm{C}\right]$ & Time [h] & Yield [\%] \\
\hline $1^{a}$ & water & 30 & 4 & $45^{b}(3 a)$ \\
\hline $2^{\mathrm{a}}$ & water & 20 & 4 & $49^{b}(3 a)$ \\
\hline 3 & pH 7 buffer & 20 & 3 & $87(3 a)$ \\
\hline
\end{tabular}

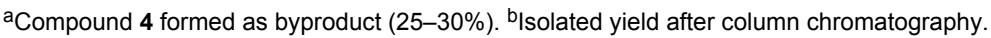

ated from the corresponding phenylacetic acid and potassium carbonate, was used in excess amounts to suppress competing 'simple' decarboxylation $\left(-\mathrm{CO}_{2}{ }^{-} \leftrightarrow-\mathrm{H}\right.$ exchange) reactions to the corresponding toluene derivatives [25].

Following the established protocol and utilizing a 1:1 acetone/ water mixture as reaction medium [27,30], irradiations with UVB light ( $300 \pm 30 \mathrm{~nm}$ ) for 4 hours under nitrogen purging in Pyrex flasks (cutoff: $<300 \mathrm{~nm}$ [47]) furnished the desired addition product 3a in yields of 45 and $49 \%$ (Table 1, entries 1 and 2). The $\mathrm{pH}$ raised from approx. 7.5 at the beginning to about 11.5 at the end of each irradiation experiment. In both cases, the tetracyclic oxazolidine compound $\mathbf{4}$, originating from intramolecular nucleophilic substitution, was obtained as a byproduct in $25-30 \%$. Noteworthy, compound $\mathbf{4}$ is formed as the only product when 1a is treated with organometallic reagents [48-50]. When the photoreaction was repeated in a 1:1 mixture of acetone and $\mathrm{pH} 7$ buffer at $20^{\circ} \mathrm{C}$ [28], the formation of $\mathbf{4}$ was prevented and the desired benzylated hydroxyphthalimidine 3a precipitated during irradiation for 3 hours. Subsequently, 3a was obtained in an excellent yield of $87 \%$ by simple filtration and washing (Table 1, entry 3 ). The $\mathrm{pH}$ increased from about 7.8 at the start to ca. 8.7 at the end of the irradiation. Temperature control was crucial as thermal conversion of $\mathbf{3 a}$ into $\mathbf{4}$ was found to occur above $40{ }^{\circ} \mathrm{C}$. Compound 1a could be converted quantitatively to the oxazolidine derivative 4 by treatment with either sodium carbonate or potassium tert-butoxide in acetonitrile.

Mixtures of $\mathrm{N}$-(bromoalkyl)phthalimides $\mathbf{1}$ and phenylacetates 2 in acetone/pH 7 buffer were subsequently irradiated with UVB light for 2-4 hours (Scheme 3 and Table 2). With the $N$-(2bromoethyl)- and $N$-(3-bromopropyl)phthalimides $\mathbf{1 a}$ and $\mathbf{1 b}$, the desired benzylated products $\mathbf{3} \mathbf{a}-\mathbf{q}$ were obtained as colorless crystalline solids in good to excellent yields of $63-95 \%$ (Table 2, entries 1-17). In many cases, the photoproducts 3 simply precipitated during irradiation or after removal of the co-solvent acetone and could be isolated by filtration. In all other cases, the desired products 3 were obtained after extraction and subsequent column chromatography. All compounds 3 showed a characteristic pair of doublets between 3 and $4 \mathrm{ppm}$ with a large geminal ${ }^{2} J$ coupling of $12-16 \mathrm{~Hz}$ for the benzylic

Table 2: Experimental results for photodecarboxylative additions.

\begin{tabular}{|c|c|c|c|c|}
\hline Entry & $n$ & $\mathrm{R}$ & Time [h] & Yield 3 [\%] \\
\hline 1 & $2(1 a)$ & $\mathrm{H}(\mathbf{2 a})$ & 3 & $87(3 a)$ \\
\hline 2 & $2(1 a)$ & $4-F(2 b)$ & 3 & $83(3 b)$ \\
\hline 3 & $2(1 a)$ & $4-\mathrm{Cl}(2 \mathrm{c})$ & 3 & $79(3 c)$ \\
\hline 4 & $2(1 a)$ & $4-\operatorname{Br}(2 d)$ & 3 & $63(3 d)$ \\
\hline 5 & $2(1 a)$ & 4-MeO (2e) & 3 & $85(3 e)$ \\
\hline 6 & $2(1 a)$ & 4-Me (2f) & 3 & $88(3 f)$ \\
\hline 7 & $2(1 a)$ & 3-Me (2g) & 3 & $66(3 \mathbf{g})$ \\
\hline 8 & $2(1 a)$ & 2-Me (2h) & 3 & $71(3 h)$ \\
\hline 9 & $2(1 a)$ & 4-AcO (2i) & 2 & $77(3 \mathbf{i})$ \\
\hline 10 & 3 (1b) & $\mathrm{H}(\mathbf{2 a})$ & 3 & $95(\mathbf{3} \mathbf{j})$ \\
\hline 11 & $3(1 b)$ & $4-F(2 b)$ & 3 & $75(3 k)$ \\
\hline 12 & $3(1 b)$ & $4-\mathrm{Cl}(2 \mathrm{c})$ & 3 & $80(3 \mathrm{I})$ \\
\hline 13 & $3(1 b)$ & $4-B r(2 d)$ & 3 & $73(3 m)$ \\
\hline 14 & $3(1 b)$ & $4-\mathrm{MeO}(\mathbf{2 e})$ & 3 & $76(3 n)$ \\
\hline 15 & $3(1 b)$ & $4-\mathrm{Me}(2 \mathrm{f})$ & 3 & $89(30)$ \\
\hline 16 & 3 (1b) & 3-Me (2g) & 3 & $91(3 p)$ \\
\hline 17 & $3(1 b)$ & 2-Me (2h) & 3 & $73(\mathbf{3 q})$ \\
\hline $18^{a}$ & $2(1 a)$ & $\mathrm{H}(\mathbf{2 a})$ & 6 & $26(3 a)^{b}$ \\
\hline 19 & $1(\mathbf{1 c})$ & $\mathrm{H}(\mathbf{2 a})$ & 4 & $37(5)$ \\
\hline
\end{tabular}

${ }^{a}$ Exposure to sunlight in a solar float. ${ }^{b} 47 \%$ conversion of $1 \mathrm{a}$.<smiles>[R]c1ccc(CC2(O)c3ccccc3C(=O)N2Cc2ccc(Br)cc2)cc1</smiles> 
methylene group $\left(-\mathrm{CH}_{2} \mathrm{Ar}\right)$ in their ${ }^{1} \mathrm{H}$ NMR spectra and a singlet at $90 \pm 3 \mathrm{ppm}$ for the newly formed tertiary alcohol $(C-\mathrm{OH})$ in their ${ }^{13} \mathrm{C}$ NMR spectra, respectively. Small amounts $(<10 \%)$ of non-volatile toluene derivatives were occasionally detected in the crude products by ${ }^{1} \mathrm{H}$ NMR spectroscopic analysis but no attempts were made to isolate these compounds. The reaction was additionally studied with natural sunlight [51,52]. Solutions of 1a and 2a were exposed to direct sunlight in a solar float developed by Liu and co-workers [53,54]. After 6 hours of illumination, the reaction had reached a conversion of $47 \%$ and 3a was subsequently isolated by column chromatography in $26 \%$ yield (Table 2, entry 18 ).

The structures of the photoaddition products $\mathbf{3 a}$ and $\mathbf{3 b}$ were unambiguously confirmed by X-ray crystallography (Figure 2). In the solid state, molecules of both compounds undergo hydrogen bonding between the newly formed hydroxy group and the intact carbonyl group, resulting in a one-dimensional network (see Supporting Information File 1).

Notably, irradiation of $N$-(bromomethyl)phthalimide (1c) in the presence of phenylacetate (2a) did not furnish the desired addition product, but the benzylated ester 5 in $37 \%$ yield instead (Scheme 4). The electron-withdrawing character of the phthalimide group favored thermal nucleophilic substitution between 1c and phenylacetate (2a) to phthalimide 6. Ester $\mathbf{6}$ was indeed obtained in $37 \%$ yield by gently heating a mixture of phthal- imide 1c and phenylacetate (2a) in acetone/water. Subsequently, compound $\mathbf{5}$ was independently prepared by photodecarboxylative benzylation of 6 for $4 \mathrm{~h}$ in $91 \%$ yield.

Sulfuric acid-catalyzed dehydrations of the benzylated hydroxyphthalimidines $\mathbf{3 a - q}$ in dichloromethane at room temperature resulted in the corresponding olefins $\mathbf{7 a - q}$ in good to excellent yields of 66-95\% (Scheme 5 and Table 3). The simple reaction protocol enabled parallel operations in a Radleys Carousel 6 Plus Reaction Station ${ }^{\mathrm{TM}}$. In line with DFT calculations by Kise et al. [12] and independently by Li and Janesko [21], the thermodynamically favored $E$-isomer was obtained as the main or sole product. The high $E$-selectivity was furthermore confirmed by ${ }^{1} \mathrm{H}$ NMR analyses. The olefinic protons of the minor $Z$-isomers are shifted downfield by approx. $0.25 \mathrm{ppm}$ due to the shielding effect of the adjacent isoindolin-1-one ring [31,41]. A similar but deshielding effect was found for the $N$-bromoalkyl protons and the arylmethylene group. No such shifts were observed for the corresponding major $E$-isomers.

The structure of the dehydration product $(E)$-7a was furthermore confirmed by X-ray crystallographic analysis (Figure 3). Remarkably, the phenyl group of the arylmethylene unit is positioned almost perpendicular to the isoindolinone ring. Compound $(E)-7 \mathbf{a}$ forms dimers through $\mathrm{CH}-\pi$ interactions between the phenyl ring and the olefinic $=\mathrm{CH}$ group (see Supporting Information File 1).
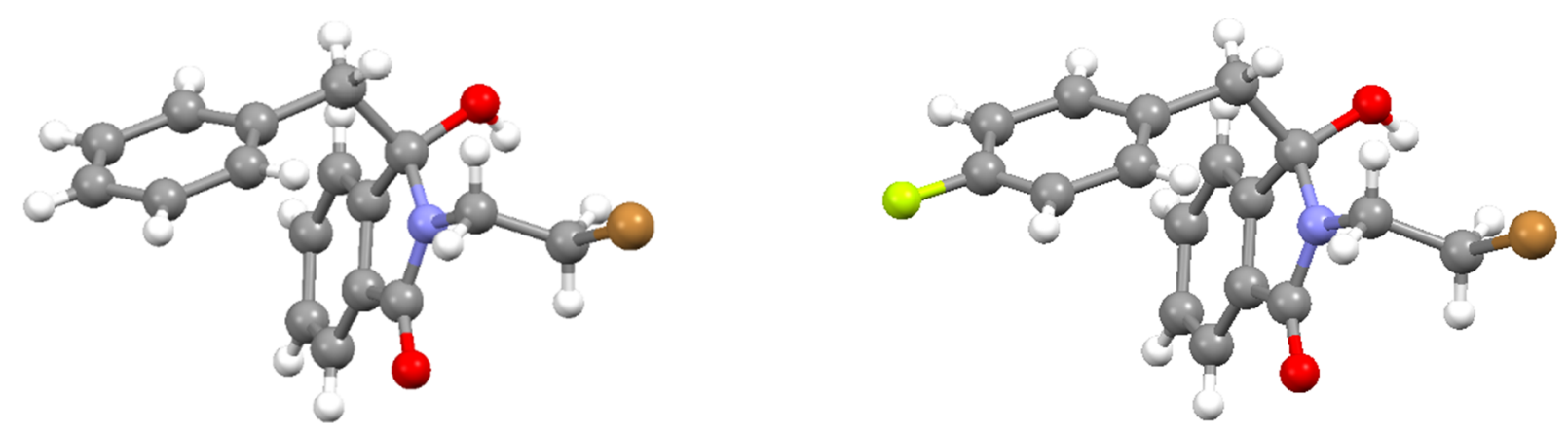

Figure 2: Crystal structures of photoaddition products $\mathbf{3 a}$ (left) and $\mathbf{3 b}$ (right).

\section{$+2 \mathbf{a} ; \Delta ;$ acetone/water}

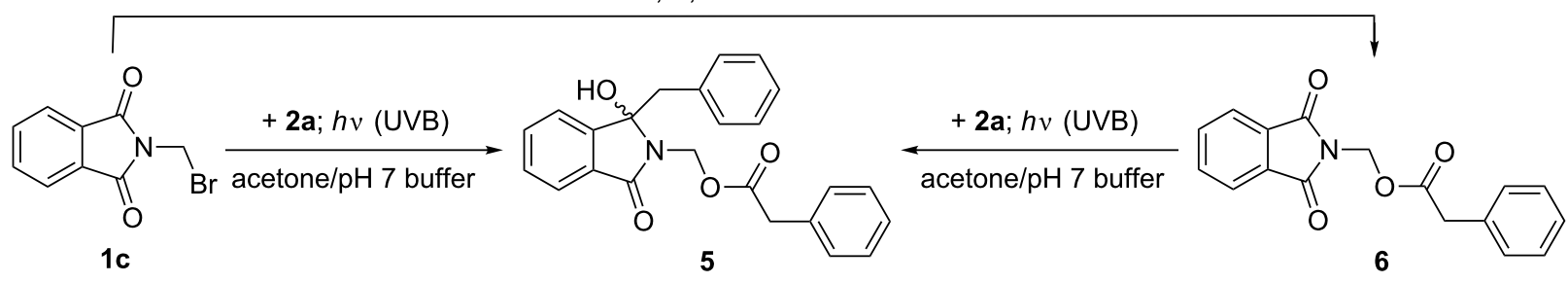


<smiles>[R]c1ccc(CC2(O)c3ccccc3C(=O)N2Br)cc1</smiles><smiles>CCCOCCO</smiles>
$\mathrm{CH}_{2} \mathrm{Cl}_{2}$<smiles>[R]c1ccccc1/C=C1\c2ccccc2C(=O)N1Br</smiles>

(Z)-7a-q (minor)

Scheme 5: Acid-catalyzed dehydration of 3a-q.

Table 3: Experimental results for acid-catalyzed dehydrations.

\begin{tabular}{lllll} 
Entry & $n$ & $\mathrm{R}$ & $E / Z$ ratio $^{\mathrm{a}}$ & Yield 7 [\%] \\
\hline 1 & 2 & $\mathrm{H}$ & $9: 1$ & $91(\mathbf{7 a})$ \\
2 & 2 & $4-\mathrm{F}$ & $>10: 1$ & $85(\mathbf{7 b})$ \\
3 & 2 & $4-\mathrm{Cl}$ & $>10: 1$ & $88(\mathbf{7 c})$ \\
4 & 2 & $4-\mathrm{Br}$ & $>10: 1$ & $83(\mathbf{7 d})$ \\
5 & 2 & $4-\mathrm{MeO}$ & $>10: 1$ & $90(\mathbf{7 e})$ \\
6 & 2 & $4-\mathrm{Me}$ & $>10: 1$ & $94(\mathbf{7 f})$ \\
7 & 2 & $3-\mathrm{Me}$ & $>10: 1$ & $83(\mathbf{7 g})$ \\
8 & 2 & $2-\mathrm{Me}$ & $>10: 1$ & $90(\mathbf{7 h})$ \\
9 & 2 & $4-\mathrm{AcO}$ & $8: 1$ & $66(\mathbf{7 i})$ \\
10 & 3 & $\mathrm{H}$ & $>10: 1$ & $83(\mathbf{7 j})$ \\
11 & 3 & $4-\mathrm{F}$ & $>10: 1$ & $91(\mathbf{7 k})$ \\
12 & 3 & $4-\mathrm{Cl}$ & $>10: 1$ & $90(\mathbf{7 l})$ \\
13 & 3 & $4-\mathrm{Br}$ & $>10: 1$ & $84(\mathbf{7 m})$ \\
14 & 3 & $4-\mathrm{MeO}$ & $>10: 1$ & $95(\mathbf{7 n})$ \\
15 & 3 & $4-\mathrm{Me}$ & $>10: 1$ & $92(\mathbf{7 o})$ \\
16 & 3 & $3-\mathrm{Me}$ & $>10: 1$ & $92(\mathbf{7 p})$ \\
17 & 3 & $2-\mathrm{Me}$ & $>10: 1$ & $83(\mathbf{7 q})$ \\
\hline
\end{tabular}

aDetermined by ${ }^{1} \mathrm{H}$ NMR analysis.

The final amination step was achieved following a modified procedure by Marzabadi and co-workers [42]. Catalytic amounts of potassium iodide were added for in situ halogen exchange. The dehydrated products $7 \mathbf{a}-\mathbf{q}$ were heated in the

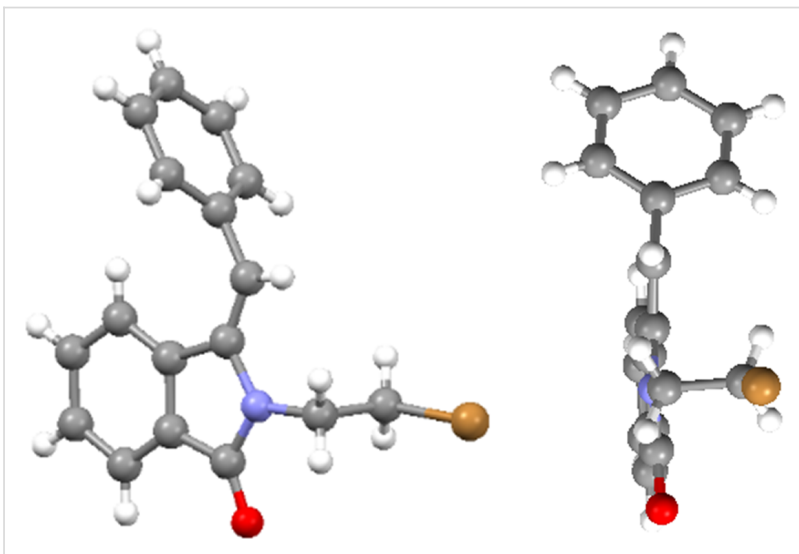

Figure 3: Crystal structure of $(E)-7 a$. Side view and front view.

presence of the respective secondary amine, $\mathrm{K}_{2} \mathrm{CO}_{3}$ and $\mathrm{KI}$ in DMF (Scheme 6 and Table 4). Subsequent work-up and isolation by column chromatography furnished the desired 2-dialkylaminoalkyl-3-arylmethylene-2,3-dihydro- $1 H$-isoindolin-1-ones $\mathbf{8 a}-\mathbf{y}$ in moderate yields of 49-61\% (Table 4), among these the biologically active AL-12 (8e), AL-12A (8i) and AL-5 (8w) in their neutral forms. Interestingly, the $Z$-isomer of $\mathbf{8 a}-\mathbf{y}$ was formed as the sole product in almost all cases as confirmed by ${ }^{1} \mathrm{H}$ NMR analyses and by comparison with literature data (Table 4, entries 1-25) [10]. Subsequent investigations revealed that $E$-to- $Z$ isomerization was caused during acidic work-up or

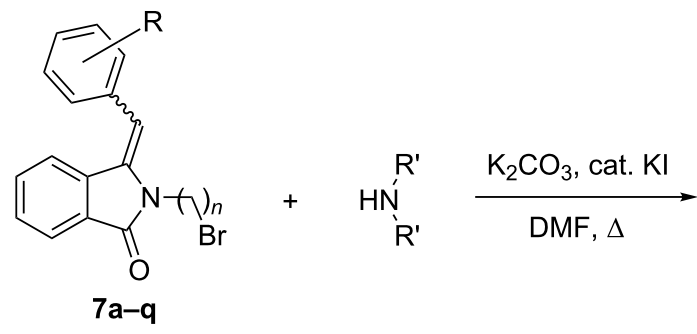

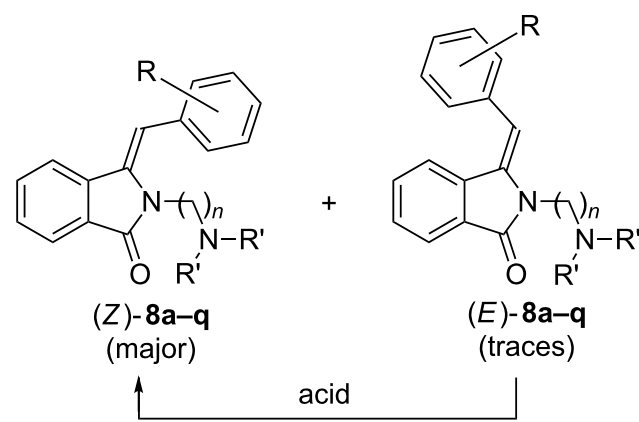


Table 4: Experimental results for amination reactions.

\begin{tabular}{|c|c|c|c|c|c|}
\hline Entry & $n$ & $\mathrm{R}$ & $\mathrm{R}^{\prime}$ & $E / Z$ ratio $^{a}$ & $\begin{array}{l}\text { Yield } 8 \\
{[\%]}\end{array}$ \\
\hline $1(7 a)$ & 2 & $\mathrm{H}$ & $\mathrm{C}_{2} \mathrm{H}_{5}$ & $>1: 10$ & $55(8 a)$ \\
\hline $2(7 b)$ & 2 & $4-\mathrm{F}$ & $\mathrm{C}_{2} \mathrm{H}_{5}$ & $>1: 10$ & $55(8 b)$ \\
\hline $3(7 c)$ & 2 & $4-\mathrm{Cl}$ & $\mathrm{C}_{2} \mathrm{H}_{5}$ & $>1: 10$ & $53(8 c)$ \\
\hline $4(7 d)$ & 2 & $4-\mathrm{Br}$ & $\mathrm{C}_{2} \mathrm{H}_{5}$ & $>1: 10$ & $51(8 d)$ \\
\hline $5(7 e)$ & 2 & 4-MeO & $\mathrm{C}_{2} \mathrm{H}_{5}$ & $>1: 10$ & $50(8 \mathrm{e})$ \\
\hline $6(7 f)$ & 2 & 4-Me & $\mathrm{C}_{2} \mathrm{H}_{5}$ & $>1: 10$ & 57 (8f) \\
\hline $7(7 g)$ & 2 & 3-Me & $\mathrm{C}_{2} \mathrm{H}_{5}$ & $>1: 10$ & $51(8 \mathrm{~g})$ \\
\hline $8(7 h)$ & 2 & 2-Me & $\mathrm{C}_{2} \mathrm{H}_{5}$ & $>1: 10$ & $58(8 \mathrm{~h})$ \\
\hline $9(7 \mathbf{i})$ & 2 & $4-\mathrm{AcO}$ & $\mathrm{C}_{2} \mathrm{H}_{5}$ & $>1: 10$ & $57(8 i)$ \\
\hline $10(7 \mathbf{j})$ & 3 & $\mathrm{H}$ & $\mathrm{C}_{2} \mathrm{H}_{5}$ & $>1: 10$ & $53(\mathbf{8 j})$ \\
\hline $11(7 k)$ & 3 & $4-\mathrm{F}$ & $\mathrm{C}_{2} \mathrm{H}_{5}$ & $>1: 10$ & $57(8 k)$ \\
\hline $12(7 \mathrm{I})$ & 3 & $4-\mathrm{Cl}$ & $\mathrm{C}_{2} \mathrm{H}_{5}$ & $>1: 10$ & $60(8 \mathrm{I})$ \\
\hline $13(7 m)$ & 3 & $4-\mathrm{Br}$ & $\mathrm{C}_{2} \mathrm{H}_{5}$ & $>1: 10$ & $59(8 m)$ \\
\hline $14(7 n)$ & 3 & 4-MeO & $\mathrm{C}_{2} \mathrm{H}_{5}$ & $>1: 10$ & $55(8 n)$ \\
\hline 15 (7o) & 3 & 4-Me & $\mathrm{C}_{2} \mathrm{H}_{5}$ & $>1: 10$ & $58(80)$ \\
\hline $16(7 p)$ & 3 & 3-Me & $\mathrm{C}_{2} \mathrm{H}_{5}$ & $>1: 10$ & $61(8 p)$ \\
\hline $17(7 q)$ & 3 & 2-Me & $\mathrm{C}_{2} \mathrm{H}_{5}$ & $>1: 10$ & $49(8 q)$ \\
\hline $18(7 a)$ & 2 & $\mathrm{H}$ & $\mathrm{CH}_{3}$ & $>1: 10$ & $58(8 r)$ \\
\hline $19(7 b)$ & 2 & $4-\mathrm{F}$ & $\mathrm{CH}_{3}$ & $>1: 10$ & $57(8 s)$ \\
\hline $20(7 c)$ & 2 & $4-\mathrm{Cl}$ & $\mathrm{CH}_{3}$ & $>1: 10$ & $55(8 t)$ \\
\hline $21(7 e)$ & 2 & 4-MeO & $\mathrm{CH}_{3}$ & $>1: 10$ & $49(8 u)$ \\
\hline $22(7 f)$ & 2 & 4-Me & $\mathrm{CH}_{3}$ & $>1: 10$ & $60(8 v)$ \\
\hline $23(7 \mathbf{j})$ & 3 & $\mathrm{H}$ & $\mathrm{CH}_{3}$ & $>1: 10$ & $58(8 w)$ \\
\hline $24(7 k)$ & 3 & $4-\mathrm{F}$ & $\mathrm{CH}_{3}$ & $>1: 10$ & $55(8 x)$ \\
\hline $25(7 q)$ & 3 & 2-Me & $\mathrm{CH}_{3}$ & $>1: 10$ & $53(8 y)$ \\
\hline $26(7 a)$ & 2 & $\mathrm{H}$ & $\mathrm{C}_{2} \mathrm{H}_{5}$ & $>10: 1^{b} / 1: 1^{c}$ & $65(8 a)$ \\
\hline $27(7 \mathbf{j})$ & 3 & $\mathrm{H}$ & $\mathrm{C}_{2} \mathrm{H}_{5}$ & $>10: 1^{b} / 10: 7^{c}$ & $72(8 \mathbf{j})$ \\
\hline
\end{tabular}

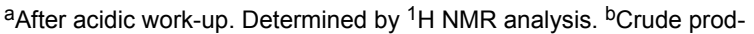
uct after neutral work-up. ${ }^{C}$ Pure product after neutral work-up followed by column chromatography on silica gel. purification. When products $\mathbf{8 a}$ and $\mathbf{8 j}$ were isolated by extraction under neutral conditions, the high $E$-selectivity of the dehydration step was retained. After column chromatographic purification on silica gel, partial isomerization to the $Z$-isomers was again observed (Table 4, entries 26 and 27).

The solid state structure of the amination product $(Z)-\mathbf{8 a}$ was furthermore established by X-ray crystal structure analysis (Figure 4). The phenyl group of the arylmethylene unit is positioned almost perpendicular to the isoindolinone ring on top of one of the $N$-ethyl groups of the side chain.
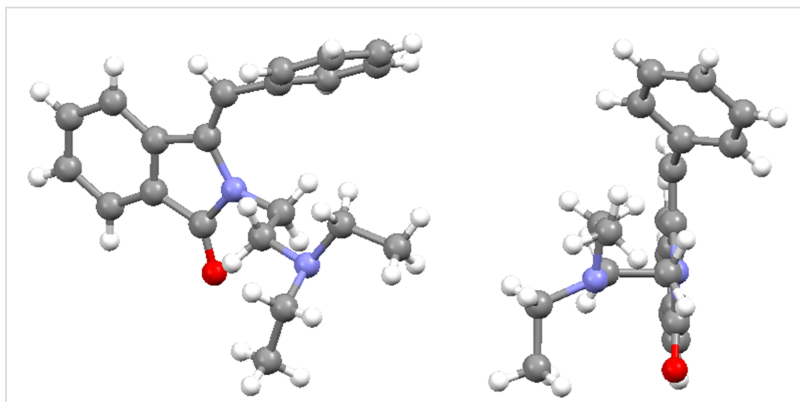

Figure 4: Crystal structure of (Z)-8a. Side view and front view.

The mechanism of the photodecarboxylation is well established (Scheme 7) and involves triplet sensitization by acetone and electron transfer between the phenylacetate and the excited phthalimide [55-57]. Subsequent decarboxylation, radical combination and protonation furnishes the observed benzylated hydroxyphthalimidine derivatives $\mathbf{3 a}-\mathbf{q}$.

The nucleophilic cyclization to the oxazolidine derivative 4 may occur at different stages of the photodecarboxylation

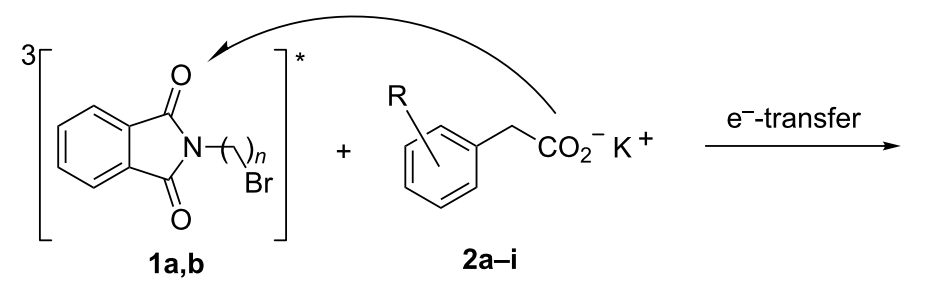<smiles>[R]c1ccc(CC2(O)c3ccccc3C(=O)N2CBr)cc1</smiles><smiles>O=C(O)[Mg]O</smiles><smiles>[R]c1ccc(CC2([O-])c3ccccc3C(=O)N2Br)cc1</smiles><smiles>CCCCCCC</smiles>

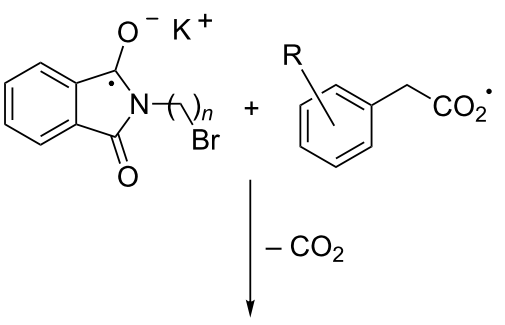


(Scheme 8). The phthalimide radical anion may undergo nucleophilic cyclization prior to $\mathrm{C}-\mathrm{C}$ bond formation (path A), as postulated by Griesbeck et al. for the photocyclization of phthaloyl-L-methionine [58]. Alternatively, the alcoholate obtained after $\mathrm{C}-\mathrm{C}$ bond formation may cyclize to the oxazolidine (path B), as known from reactions of $\mathbf{1 a}$ with organometallic reagents [48-50]. When compound 1a was treated with either sodium carbonate or potassium tert-butoxide it was indeed converted quantitatively to the oxazolidine derivative 4. Similarly, the final benzylated hydroxyphthalimidine may undergo cyclization instead (path C), as was found to occur at elevated temperature of $>40{ }^{\circ} \mathrm{C}$. Temperature control during the reaction, work-up and isolation was thus important to suppress this undesired transformation. The usage of $\mathrm{pH} 7$ buffer as a co-solvent significantly improved yields and selectivity, possibly due to the avoidance of extreme basic conditions found for photodecarboxylations in acetone/water [34,59].

The high stereoselectivity during the formation of compounds $\mathbf{7 a}-\mathbf{q}$ is supported by the higher stability of the $E$-isomer, as shown for other simple $N$-substituted benzylideneisoindolin-1ones [12,21]. Remarkably, acidic reaction conditions induced thermal isomerization of compounds $\mathbf{8 a}-\mathbf{y}$, possibly via an acylaminium cation intermediate (Scheme 9) [60]. The change in stability may be caused by a stabilizing ionic- $\pi$ interaction for the $Z$-isomer during isomerization [61]. A similar thermal isomerization towards the more stable isomer induced by catalytic amounts of pyridinium $p$-toluenesulfonate has been recently reported by Kise and co-workers [12].

\section{Conclusion}

Photodecarboxylation reactions are emerging as versatile transformations in organic synthesis $[24,33,62-65]$. The photodecarboxylative addition of phenylacetates to $N$-(bromoalkyl)phthalimides was used as a mild key step in the synthesis of 2-dialkylaminoalkyl-3-arylmethylene-2,3-dihydro- $1 H$-isoindolin-1-ones, among these the potent local anesthetics AL-12, AL-12A and AL-5 (in their neutral forms). The simple procedures make this three-step process attractive for in-series continuous flow applications $[40,66,67]$.

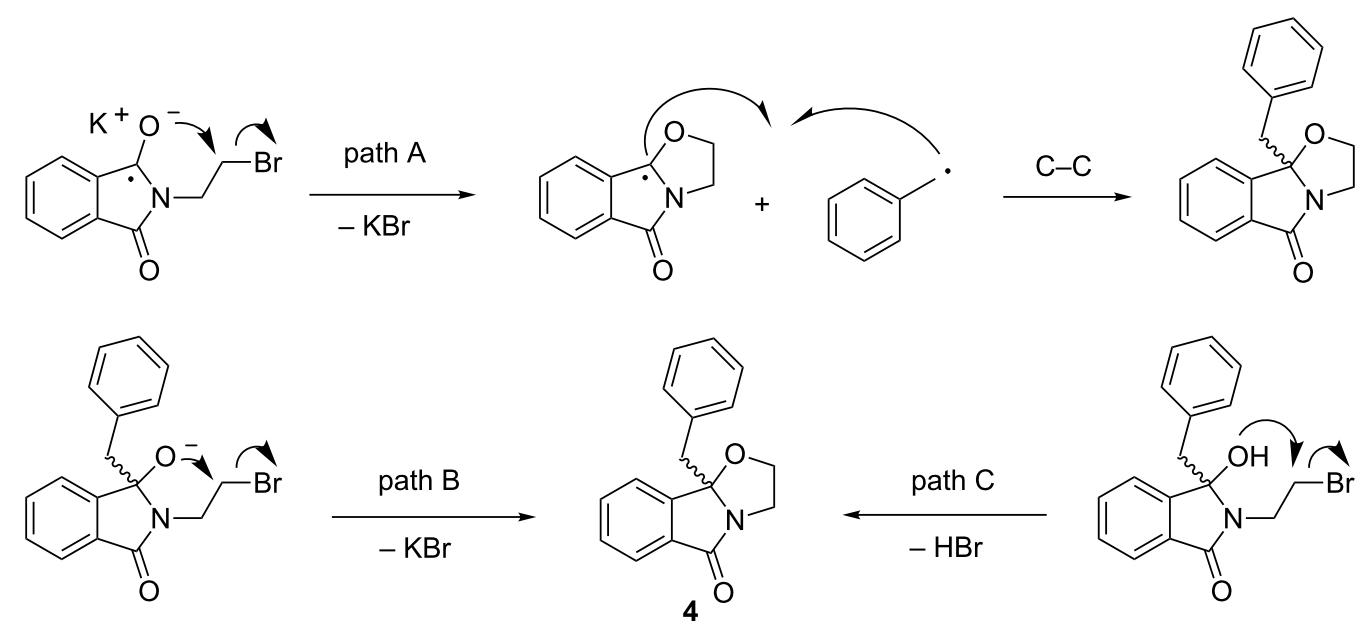

Scheme 8: Possible scenarios for nucleophilic cyclization to 4<smiles>[R]c1ccccc1/C=C1\c2ccccc2C(=O)N1[N+]([R])=[V]</smiles><smiles>[R][R](=[R])N1C(=O)c2ccccc2C1=Cc1ccccc1[R]</smiles>

$E$-isomer of $\mathbf{8}$<smiles>[R][R]([R])=NC1=[N+](C=Cc2ccccc2[R])c2ccccc2C1=O</smiles><smiles>[C+]#C[PH+]</smiles>
$+\mathrm{H}^{+}$<smiles>[R]N([Tl])N1CCC2=CC=CC2C1=O</smiles>

Z-isomer of $\mathbf{8}$ 


\section{Supporting Information}

\section{Supporting Information File 1}

Experimental details, detailed spectroscopic and crystallographic data.

[http://www.beilstein-journals.org/bjoc/content/ supplementary/1860-5397-13-275-S1.pdf]

\section{Acknowledgements}

This work was financially supported by the Australian Research Council (ARC, DP130100794). SM thanks the Higher Education Commission Pakistan for providing a Scholarship under the International Research Support Initiative Program. MO thanks Professor Emeritus Robert (Bob) S. H. Liu from the University of Hawaii for the donation of the solar float reactor.

\section{ORCID ${ }^{\circledR}$ iDs}

Ommid Anamimoghadam - https://orcid.org/0000-0002-7350-3472 Jun Wang - https://orcid.org/0000-0001-8744-5181

Michael Oelgemöller - https://orcid.org/0000-0003-3541-6770

\section{References}

1. Kushwaha, N.; Kaushik, D. J. Appl. Pharm. Sci. 2016, 6, 159-171. doi:10.7324/JAPS.2016.60330

2. Frlan, R.; Gobec, S. Expert Opin. Ther. Pat. 2017, 27, 637-641. doi:10.1080/13543776.2017.1322954

3. Bhatia, R. K. Curr. Top. Med. Chem. 2017, 17, 189-207. doi:10.2174/1568026616666160530154100

4. Sharma, U.; Kumar, P.; Kumar, N.; Singh, B. Mini-Rev. Med. Chem. 2010, 10, 678-704. doi:10.2174/138955710791572442

5. Speck, K.; Magauer, T. Beilstein J. Org. Chem. 2013, 9, 2048-2078. doi:10.3762/bjoc.9.243

6. Csende, F.; Stájer, G. Curr. Org. Chem. 2005, 9, 1261-1276. doi:10.2174/1385272054863961

7. Csende, F.; Miklós, F.; Stájer, G. Curr. Org. Chem. 2012, 16, 1005-1050. doi:10.2174/138527212800194683

8. Marsili, A. 2-(Omega-alkylaminoalkyl)-and (2-omega-dialkylaminoalkyl-3-(4-X-benxylidene)-phthalimidines. Eur. Pat. Appl. EP-0105131A1, April 11, 1984. Chem. Abstr. 1984, 101, 54922.

9. Becker, D. E.; Reed, K. L. Anesth. Prog. 2012, 59, 90-102. doi:10.2344/0003-3006-59.2.90

10. Couture, A.; Deniau, E.; Grandclaudon, P. Tetrahedron 1997, 53, 10313-10330. doi:10.1016/S0040-4020(97)00680-7

11. Li, L.; Wang, M.; Zhang, X.; Jiang, Y.; Ma, D. Org. Lett. 2009, 11, 1309-1312. doi:10.1021/ol9000922

12. Kise, N.; Kawano, Y.; Sakurai, T. J. Org. Chem. 2013, 78, 12453-12459. doi:10.1021/jo402125u

13. Zhang, L.; Zhang, Y.; Wang, X.; Shen, J. Molecules 2013, 18 , 654-665. doi:10.3390/molecules 18010654

14. Chatterjee, N.; Sarkar, S.; Pal, R.; Sen, A. K. Tetrahedron Lett. 2013, 54, 3748-3751. doi:10.1016/j.tetlet.2013.05.004

15. Irudayanathan, F. M.; Noh, J.; Choi, J.; Lee, S. Adv. Synth. Catal. 2014, 356, 3433-3442. doi:10.1002/adsc.201400451
16. Reyes-González, M. Á.; Zamudio-Medina, Á.; Ramírez-Marroquín, O. A.; Ordóñez, M. Monatsh. Chem. 2014, 145 , 1001-1007. doi:10.1007/s00706-013-1146-9

17. Gogoi, A.; Guin, S.; Rout, S. K.; Majji, G.; Patel, B. K. RSC Adv. 2014, 4, 59902-59907. doi:10.1039/C4RA12782J

18. Zheng, X.-X.; Du, C.; Zhao, X.-M.; Zhu, X.; Suo, J.-F.; Hao, X.-Q.; Niu, J.-L.; Song, M.-P. J. Org. Chem. 2016, 81, 4002-4011. doi:10.1021/acs.joc.6b00129

19. Pathare, R. S.; Sharma, S.; Elagandhula, S.; Saini, V.; Sawant, D. M.; Yadav, M.; Sharon, A.; Khan, S.; Pardasani, R. T. Eur. J. Org. Chem. 2016, 5579-5587. doi:10.1002/ejoc.201600999

20. Pal, R.; Chatterjee, N.; Roy, M.; Nouh, E. S. A.; Sarkar, S.; Jaisankar, P.; Sarkar, S.; Sen, A. K. Tetrahedron Lett. 2016, 57, 43-47. doi:10.1016/j.tetlet.2015.11.059

21. Li, L.; Janesko, B. G. J. Org. Chem. 2016, 81, 10802-10808. doi:10.1021/acs.joc.6b01904

22. Munoz, S. B.; Aloia, A. N.; Moore, A. K.; Papp, A.; Mathew, T.; Fustero, S.; Olah, G. A.; Prakash, G. K. S. Org. Biomol. Chem. 2016, 14, 85-92. doi:10.1039/C5OB02187A

23. Griesbeck, A. G.; Oelgemöller, M. Synlett 1999, 492-494. doi:10.1055/s-1999-2622

24. Griesbeck, A. G.; Kramer, W.; Oelgemöller, M. Synlett 1999, 1169-1178. doi:10.1055/s-1999-3159

25. Oelgemöller, M.; Cygon, P.; Lex, J.; Griesbeck, A. G. Heterocycles 2003, 59, 669-684. doi:10.3987/COM-02-S77

26. Griesbeck, A. G.; Warzecha, K.-D.; Neudörfl, J. M.; Görner, H. Synlett 2004, 2347-2350. doi:10.1055/s-2004-832850

27. Hatoum, F.; Gallagher, S.; Baragwanath, L.; Lex, J.; Oelgemöller, M. Tetrahedron Lett. 2009, 50, 6335-6338. doi:10.1016/j.tetlet.2009.08.115

28. Belluau, V.; Noeureuil, P.; Ratzke, E.; Skvortsov, A.; Gallagher, S.; Motti, C. A.; Oelgemöller, M. Tetrahedron Lett. 2010, 51, 4738-4741. doi:10.1016/j.tetlet.2010.07.017

29. Griesbeck, A. G.; Nazarov, N.; Neudörfl, J. M.; Heffen, M. Green Chem. 2012, 14, 3004-3006. doi:10.1039/c2gc36089f

30. Hatoum, F.; Engler, J.; Zelmer, C.; Wißen, J.; Motti, C. A.; Lex, J.; Oelgemöller, M. Tetrahedron Lett. 2012, 53, 5573-5577. doi:10.1016/j.tetlet.2012.07.142

31. Griesbeck, A. G.; Neudörfel, J.-M.; Goldfuss, B.; Molitor, S. ChemPhotoChem 2017, 1, 355-362. doi:10.1002/cptc.201700057

32. Capaldo, L.; Buzzetti, L.; Merli, D.; Fagnoni, M.; Ravelli, D. J. Org. Chem. 2016, 81, 7102-7109. doi:10.1021/acs.joc.6b00984

33. Budac, D.; Wan, P. J. Photochem. Photobiol., A: Chem. 1992, 67, 135-166. doi:10.1016/1010-6030(92)85224-I

34. Griesbeck, A. G.; Kramer, W.; Oelgemöller, M. Green Chem. 1999, 1, 205-208. doi:10.1039/a905076k

35. Griesbeck, A. G.; Maptue, N.; Bondock, S.; Oelgemöller, M. Photochem. Photobiol. Sci. 2003, 2, 450-451. doi:10.1039/B212357F

36. Shvydkiv, O.; Gallagher, S.; Nolan, K.; Oelgemöller, M. Org. Lett. 2010, 12, 5170-5173. doi:10.1021/ol102184u

37. Shvydkiv, O.; Nolan, K.; Oelgemöller, M. Beilstein J. Org. Chem. 2011, 7, 1055-1063. doi:10.3762/bjoc.7.121

38. Oelgemöller, M.; Gallagher, S.; McCarthy, K. Processes 2014, 2, 158-166. doi:10.3390/pr2010158

39. Pordanjani, H. M.; Faderl, C.; Wang, J.; Motti, C. A.; Junk, P. C.; Oelgemöller, M. Aust. J. Chem. 2015, 68, 1662-1667. doi:10.1071/CH15356

40. Josland, S.; Mumtaz, S.; Oelgemöller, M. Chem. Eng. Technol. 2016, 39, 81-87. doi:10.1002/ceat.201500285 
41. Ang, W. S.; Halton, B. Aust. J. Chem. 1971, 24, 851-856. doi:10.1071/CH9710851

42. Jiang, Y.; Chen, C.-A.; Lu, K.; Daniewska, I.; De Leon, J.; Kong, R.; Forray, C.; Li, B.; Hegde, L. G.; Wolinsky, T. D.; Craig, D. A.; Wetzel, J. M.; Anderson, K.; Marzabadi, M. R. J. Med. Chem. 2007, 50 , 3870-3882. doi:10.1021/jm060381c

43. Oelgemöller, M.; Griesbeck, A. G. J. Photochem. Photobiol., C: Photochem. Rev. 2002, 3, 109-127. doi:10.1016/S1389-5567(02)00022-9

44. McDermott, G.; Yoo, D. J.; Oelgemöller, M. Heterocycles 2005, 65, 2221-2257. doi:10.3987/REV-05-601

45. Coyle, J. D.; Smart, L. E.; Challiner, J. F.; Haws, E. J. J. Chem. Soc., Perkin Trans. 1 1985, 121-129. doi:10.1039/p19850000121

46. Coyle, J. D.; Bryant, L. R. B.; Cragg, J. E.; Challiner, J. F.; Haws, E. J. J. Chem. Soc., Perkin Trans. 1 1985, 1177-1180. doi:10.1039/p19850001177

47. Montalti, M.; Credi, A.; Prodi, L.; Gandolfi, M. T. Handbook of Photochemistry, 3rd ed.; CRC Press: Boca Raton, United States, 2006; pp $599 \mathrm{ff}$.

48. Bousquet, T.; Fleury, J.-F.; Daïch, A.; Netchitaïlo, P. Tetrahedron 2006, 62, 706-715. doi:10.1016/j.tet.2005.10.017

49. Wharton, C. J.; Wrigglesworth, R. J. Chem. Soc., Perkin Trans. 11985 , 809-813. doi:10.1039/p19850000809

50. Torian, B. E.; Braun, L. L. J. Heterocycl. Chem. 1984, 21, 293-295. doi:10.1002/jhet.5570210204

51. Yoshimi, Y.; Nishio, A.; Hayashi, M.; Morita, T. J. Photochem. Photobiol., A: Chem. 2016, 331, 17-21. doi:10.1016/j.jphotochem.2016.03.012

52. Oelgemöller, M. Chem. Rev. 2016, 116, 9664-9682. doi:10.1021/acs.chemrev.5b00720

53. Zhao, Y.-P.; Campbell, R. O.; Liu, R. S. H. Green Chem. 2008, 10, 1038-1042. doi:10.1039/b809007f

54.Zhao, Y.-P.; Yang, L.-Y.; Liu, R. S. H. Green Chem. 2009, 11, 837-842. doi:10.1039/b819207c

55. Warzecha, K.-D.; Görner, H.; Griesbeck, A. G. J. Phys. Chem. A 2006, 110, 3356-3363. doi:10.1021/jp055878x

56. Görner, H.; Griesbeck, A. G.; Heinrich, T.; Kramer, W.; Oelgemöller, M. Chem. - Eur. J. 2001, 7, 1530-1538.

doi:10.1002/1521-3765(20010401)7:7<1530::AID-CHEM1530>3.0.CO; 2-L

57. Görner, H.; Oelgemöller, M.; Griesbeck, A. G. J. Phys. Chem. A 2002, 106, 1458-1464. doi:10.1021/jp011090c

58. Griesbeck, A. G.; Mauder, H.; Müller, I.; Peters, E.-M.; Peters, K.; von Schnering, H. G. Tetrahedron Lett. 1993, 34, 453-456. doi:10.1016/0040-4039(93)85100-B

59. Griesbeck, A. G.; Heinrich, T.; Oelgemöller, M.; Molis, A.; Heidtmann, A. Helv. Chim. Acta 2002, 85, 4561-4578. doi:10.1002/hlca.200290027

60. Maryanoff, B. E.; Zhang, H.-C.; Cohen, J. H.; Turchi, I. J.; Maryanoff, C. A. Chem. Rev. 2004, 104, 1431-1628. doi:10.1021/cr0306182

61. Salonen, L. M.; Ellermann, M.; Diederich, F. Angew. Chem., Int. Ed. 2011, 50, 4808-4842. doi:10.1002/anie.201007560

62. Jin, Y.; Fu, H. Asian J. Org. Chem. 2017, 6, 368-385. doi:10.1002/ajoc.201600513

63. Xuan, J.; Zhang, Z.-G.; Xiao, W.-J. Angew. Chem., Int. Ed. 2015, 54, 15632-15641. doi:10.1002/anie.201505731

64. Yoshimi, Y. J. Photochem. Photobiol., A: Chem. 2017, 342, 116-130. doi:10.1016/j.jphotochem.2017.04.007
65. Yoshimi, Y. J. Synth. Org. Chem., Jpn. 2013, 71, 935-943. doi:10.5059/yukigoseikyokaishi.71.935

66. Plutschack, M. B.; Pieber, B.; Gilmore, K.; Seeberger, P. H. Chem. Rev. 2017, 117, 11796-11893.

doi:10.1021/acs.chemrev.7b00183

67. Webb, D.; Jamison, T. F. Chem. Sci. 2010, 1, 675-680. doi:10.1039/c0sc00381f

\section{License and Terms}

This is an Open Access article under the terms of the Creative Commons Attribution License

(http://creativecommons.org/licenses/by/4.0), which permits unrestricted use, distribution, and reproduction in any medium, provided the original work is properly cited.

The license is subject to the Beilstein Journal of Organic Chemistry terms and conditions: (http://www.beilstein-journals.org/bjoc)

The definitive version of this article is the electronic one which can be found at: doi: $10.3762 /$ bjoc. 13.275 